\title{
Epidemiology and outcome of 1442 pediatric burn patients: A single-center experience
}

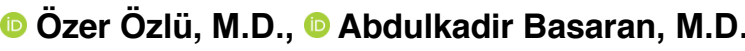

Department of General Surgery, Adana City Training and Research Hospital, Adana-Turkey

\begin{abstract}
BACKGROUND: Burns are common injuries among children resulting with significant mortality and morbidity, especially in developing countries. Epidemiological data may guide for the preventive measures and contribute reducing the incidence of burns in children. The aim of this study is to report the epidemiological features of pediatric burn patients treated in a tertiary burn center and to suggest preventive measures.
\end{abstract}

METHODS: Between January I, 2015, and June 30, 2019, a total of I442 children hospitalized in our burn center were evaluated retrospectively. Demographic, epidemiological, and clinical data including burn etiology, percentage of burned total body surface area (TBSA), hospital stay, infection, and mortality rate were reported.

RESULTS: The percentage of burned TBSA was II.23 \pm 10.70 and the length of hospital stay was $14.38 \pm 18.1$ days. In total, $89.18 \%$ of the patients $(n=1286)$ experienced burn injury indoors. With regard to the etiology, scalding with hot water and tea was the most common in all age groups. Flame burn incidence increases after infancy, and electrical burns occur more in school age. A total of 10 patients $(0.69 \%)$ were died and seven of them were delayed referrals from other hospitals.

CONCLUSION: Infants and males consist of the majority of our pediatric burn patients. The percentage of burned TBSA and length of hospital stay increased as the patient age increased. Childhood burn injuries are mainly scald burns that occur indoors, while their parents were nearby. Therefore, education programs focusing on primary prevention addressing family members are required to avoid pediatric burns.

Keywords: : Burn; epidemiology; pediatric patients; prevention.

\section{INTRODUCTION}

Burns are among important causes of mortality and morbidity in developing countries. According to the data of the World Health Organization, more than $95 \%$ of deaths due to flame burns occur in low- and middle-income countries. The mortality rate due to flame burns is $6.4 / 100,000$ in countries in the Eastern Mediterranean region. This rate is $1.0 / 100,000$ in developed countries. This is the highest difference seen for any mechanism of injury. Burn prevention strategies including the use of smoke detectors, regulation of water heater temperatures, flameproof children's clothing, and the use of fire resistant electrical cables are among the measures and policy changes implemented by high-income countries to re- duce burden of burn injuries. ${ }^{[1]}$ Although these strategies have been successful in most of the developed countries, burn-related mortality rates still remain unacceptably high in lowand middle-income countries. ${ }^{[2]}$ The main reason for this is a limited awareness of the size and cost of the problem at the level of policy-makers. There is also a lack of awareness about the fact that the high mortality, disability, and deformity rates seen after burns can be reduced with affordable and sustainable methods in prevention and burn care.

In general, true identification of the problem is considered to be the major component of planning effective interventions. Unfortunately in many countries with more limited resources, data on burns are few or inadequate. Burns are common

Cite this article as: Özlü Ö, Basaran A. Epidemiology and outcome of 1442 pediatric burn patients: A single-center experience. Ulus Travma Acil Cerrahi Derg 2022;28:57-61.

Address for correspondence: Özer Özlü, M.D.

Adana Şehir Eğitim ve Araştırma Hastanesi, Genel Cerrahi Anabilim Dalı, Adana, Turkey

Tel: +90322 - 4559000 E-mail: ozerozlu5757@yahoo.com

Ulus Travma Acil Cerrahi Derg 2022;28(I):57-6I DOI: 10.14744/tjtes.2020.69447 Submitted: 09.09.2020 Accepted: 05.10.2020

Copyright 2022 Turkish Association of Trauma and Emergency Surgery 
injuries among children. Effective strategies are essential to reduce these injuries, many of which are preventable. Epidemiological data are important to define the population at risk thoroughly, to suggest appropriate preventive measures, and to formulate a policy. ${ }^{[3,4]}$ Therefore, the aim of this study is to examine the epidemiological and clinical features of pediatric burn patients treated in a burn center and to suggest preventive measures.

\section{MATERIALS AND METHODS}

In this study, a total of I442 children hospitalized in our burn center between January I, 2015, and June 30, 2019, are evaluated. The demographic data, epidemiological data (place of burn, burn etiology, and mechanism), and clinical variables (percentage of burned total body surface area (TBSA), hospital stay, infection, and mortality rate) are evaluated retrospectively from patient files and the hospital registries.

This study was approved by the local Clinical Research Ethical Committee of the Adana City Research and Training Hospital (Decision no: 46I/2019).

\section{Statistical Analysis}

The Statistical Package for the Social Sciences 20.0 for Windows was used for the analysis of the data. The variables were checked for normal distribution. Since the data were not distributed normally, Kruskal-Wallis test was used for analysis of continuous variables and Chi-Square test was used for analysis of categorical variables. The results were expressed as mean $\pm S D$ and median (min-max), $\mathrm{n}$ and percent (\%). $\mathrm{P}<0.05$ was considered as statistically significant.

\section{RESULTS}

Between January 2015 and June 2019, a total of I442 children were hospitalized in our burn center. The mean age of the patients was $4.1 \mathrm{I} \pm 4.2$ (median age 2.5 ). About $55.2 \%$ were male $(n=796)$ and $44.8 \%$ were female $(n=646)$. The percentage of burned TBSA was $11.23 \pm 10.7$ and the length of hospital stay was found to be $14.38 \pm 18$. 1 days.
The data of the patients were evaluated according to three age groups: Group I: Infants and toddlers ( $<2$ years old), Group 2: Preschool (between 2 and 6 years old), and Group 3: School age (>6 years old). Demographic and clinical data of the patients by age groups are given in Table I.

The burn injury was occurred mainly indoors in all age groups. A total of 1286 patients (89.18\%) experienced the burn injury at home. Indoor burn ratios were $97.07 \%(n=696)$ for Group I, 90.58\% (n=404) for Group 2, and 66.66\% ( $n=186)$ for Group 3. The second most common place of burn injury was open areas. Outdoor burn ratios were $2.93 \%(n=21)$, $9.42 \%(n=42)$, and $27.6 \%(n=77)$, respectively. Only 16 patients (5.7\%) in Group 3 experienced a burn injury at workplace.

With regard to the etiology, scalds, especially with water and tea, were the most common causes in all age groups. Flame burn incidence increases after infancy, and electrical burns occur more in school age group than in other groups. The total percentage of scalds was $99.51 \%$ in Group I, $84.94 \%$ in Group 2, and 59.14\% in Group 3. The data of burn etiology regarding age groups are given in Table 2.

A total of 234 patients (24\%) of our study population were treated in intensive care unit (ICU). The percentage of ICU admission increases as the age of the patients increases: $10.32 \%$ of 717 patients ( $n=74$ ) in Group I, $20.63 \%$ of 446 patients $(n=92)$ in Group 2, and $24.37 \%$ of 279 patients $(n=68)$ in Group 3.

Infection rate was found to be $5.68 \%$ considering all patients. Among patients treated in the ICU, 30.8\% ( $n=72)$ of them experienced an infection detected by blood, urine, or wound cultures. The most common microorganisms isolated were Pseudomonas aeruginosa and Acinetobacter baumannii.

The total mortality rate of the study population was $0.69 \%$ $(n=10)$, all being treated in the ICU (Table 3). The mean TBSA values of these patients were found to be $37.4 \pm 16.4(20-55)$, 60 , and $62.5 \pm 29.0$ (35-90) for each group, respectively. Six of

Table I. Demographic and clinical data of the patients by age groups

\begin{tabular}{lcccc}
\hline & $\begin{array}{c}\text { Group I } \\
(\mathbf{n = 7 1 7 )}\end{array}$ & $\begin{array}{l}\text { Group 2 } \\
(\mathbf{n = 4 4 6 )}\end{array}$ & $\begin{array}{c}\text { Group 3 } \\
(\mathbf{n = 2 7 9 )}\end{array}$ & p-value \\
\hline Age (years) & $1.4 \pm 0.5$ & $3.83 \pm 1.1$ & $11.5 \pm 3.5$ & $<0.001$ \\
Gender (M/F) & $415 / 302$ & $235 / 211$ & $146 / 133$ & 0.126 \\
TBSA (\%) & $9.36 \pm 7.8$ & $12.54 \pm 11.4$ & $14.0 \pm 14.4$ & $<0.001$ \\
& $7.0(1-65)$ & $9.0(1-90)$ & $9.0(2-90)$ & $<0.001$ \\
Hospital stay (day) & $11.3 \pm 10.2$ & $15.6 \pm 18.5$ & $20.3 \pm 28.6$ & $12.0(1-247)$ \\
\end{tabular}

M/F: Male/Female; TBSA: Total Body Surface Area. "Values are given as mean $\pm S D$ and median (min-max). 
Table 2. Etiological data by age groups

\begin{tabular}{|c|c|c|c|}
\hline Etiology & $\begin{array}{l}\text { Group I } \\
(n=7 \mid 7)\end{array}$ & $\begin{array}{l}\text { Group } 2 \\
(n=446)\end{array}$ & $\begin{array}{r}\text { Group } 3 \\
(n=279)\end{array}$ \\
\hline \multicolumn{4}{|l|}{ Scalds } \\
\hline Water & $339(47.28)$ & $207(46.40)$ & $87(31.18)$ \\
\hline Tea & I86 (25.94) & $76(17.03)$ & $40(14.34)$ \\
\hline Meal & $67(9.34)$ & $47(10.53)$ & 22 (7.89) \\
\hline Milk & $38(5.30)$ & $25(5.60)$ & $4(1.43)$ \\
\hline Frying Oil & $19(2.65)$ & $24(5.38)$ & $12(4.30)$ \\
\hline Flame & $19(2.65)$ & $42(9.42)$ & $73(26.16)$ \\
\hline Contact & $43(6.0)$ & $16(3.62)$ & $7(2.52)$ \\
\hline Electricity & $2(0.28)$ & $5(1.12)$ & $30(10.75)$ \\
\hline Chemical & $4(0.56)$ & $4(0.90)$ & $4(1.43)$ \\
\hline
\end{tabular}

these patients were flame burns and four were scalds with hot water. Among these patients, seven of them were delayed referrals from other hospitals and all had clinical infection.

\section{DISCUSSION}

Investigations on burn epidemiology and clinical data are important to develop effective prevention approaches in childhood burns. These studies also allow different burn clinics to compare themselves in the light of available data. Our burn center is a tertiary center with $2 \mathrm{I}$ ward beds and six intensive care beds and hospitalizing about 450 patients per year from all age groups. In this study, we present our data about pediatric burns to improve the outcomes of treatment and preventive strategies and we compare our results with similar studies in the literature.

Burn treatment is costly and difficult whereas burn prevention studies are very cost effective. With burn prevention studies, burn morbidity and mortality as well as hospital stay decreased in developed countries. ${ }^{[1,5]}$ Our country was examined among low- or middle-income countries in a review on descriptive epidemiology, risk factors, treatment, and prevention of burns. ${ }^{[2]}$ Many studies discussed in this review showed that most burns occur in children $<4$ years of age. In our study, the average age of 1442 childhood burns was found to be $4.11 \pm 4.2$ (median age 2.5) in accordance with these results. However, in some studies, the median age was higher than 5 years of age. ${ }^{[6,7]}$ The high number of burns in infants and preschool children has been attributed to lack of motor coordination during their development, curiosity to know the surrounding and being active. ${ }^{[8]}$ In our study, $89.18 \%(n=1286)$ of the patients were injured indoors. There are also many reports in the literature with high childhood burn rates inside the home. ${ }^{[9-11]}$ At crowded home environment and the habit of dining on a floor table contribute to excessive childhood burns in our country. ${ }^{[6]}$ In our study, the ratio of male patients was higher in accordance with literature. ${ }^{[3,6,7,12-14]}$ In the early period of child development, boys are more active contributing male dominance. TBSA rates and length of hospital stay increased with age, as in studies reported by Albayrak et al. ${ }^{[12]}$ and $\mathrm{Li}$ et al. ${ }^{[15]}$ In the newborn and infancy period, it is reported that patients with lower TBSA are hospitalized and as the patient gets older, more severe burns are hospitalized. Furthermore, as TBSA increases, the duration of hospitalization is extended due to the long recovery period.

In our study, scalds were the most common etiology for all age groups. The ratio of scalds which was $90.5 \%$ in infancy declines to $59.1 \%$ in the school age group. Contact burns, which are more common in infancy, decrease as children become more familiar with the environment and begin to perceive the danger in older ages. As age increases, the percentage of flame and electrical burns also increases. Dangerous behaviors, unsafe playgrounds, hazardous environment, and occupational injuries are the main reasons for increased ratio of flame and electrical burns in school-aged children. In the literature, some studies including different age groups presented similar trend of etiological factor distribution as the child gets older. ${ }^{[8,13,16-18]}$

The overall infection rate was found as $5.68 \%(n=82)$. Considering the patients treated in the ICU, infection rate was

Table 3. Clinical data of intensive care unit patients

\begin{tabular}{lcccr}
\hline & $\begin{array}{c}\text { Group I } \\
(\mathbf{n = 7 4 )}\end{array}$ & $\begin{array}{c}\text { Group 2 } \\
(\mathbf{n = 9 2})\end{array}$ & $\begin{array}{c}\text { Group 3 } \\
(\mathbf{n = 6 8 )}\end{array}$ & p-value \\
\hline TBSA (\%) & $24.16 \pm 11.8$ & $28.29 \pm 15.3$ & $31.56 \pm 19.4$ & 0.002 \\
& $21.5(6-65)$ & $25.5(2-90)$ & $27.5(2-90)$ & 0.002 \\
ICU stay (day) & $10.77 \pm 10.1$ & $14.62 \pm 13.0$ & $22.5 \pm 28.5$ & $17.0(1-187)$ \\
Infection, n (\%) & $8.5(1-58)$ & $11.50(1-76)$ & $29(42.6)$ & 0.005 \\
Mortality, n (\%) & $13(17.6)$ & $30(32.6)$ & $4(5.88)$ & 0.147 \\
\hline
\end{tabular}

TBSA: Total Body Surface Area; ICU: Intensive Care Unit. "Values are given as mean \pm SD and median (min-max). 
$30.8 \%(n=72)$. The most common microbiological agents observed in the cultures of the patients were $P$. aeruginosa and A. baumannii. Infection rate increases as the percentage of TBSA and the length of hospital stay increases. Infection is also more common in late referrals, delayed admissions, presence of central venous catheters, or urinary catheters. Albayrak et al. ${ }^{[12]}$ reported similar infection rates in their study considering all age groups. The scarcity of results related to infection in childhood burns is remarkable and further studies are needed in this regard.

Our mortality rate was $0.69 \%$, which was all among the patients treated in the ICU. Of these 10 patients, seven were delayed referrals from other hospitals. No mortality was seen in patients hospitalized in the wards. Our mortality rate $(0.69 \%)$ is much lower than the rates $(9.9-21.3 \%)$ reported in a review by Forjuoh investigating burns in low- and middle-income countries in which the gender, age, and etiological characteristics of patients are similar. ${ }^{[2]}$ Furthermore, the mortality rate for all age groups has been reported as 5-37\% in patients admitted to the hospital in a review of burn epidemiology in the Eastern Mediterranean countries. ${ }^{[17]}$ In studies conducted in developed countries, the mortality rates have been reported between 0.3 and $2.7 \%$ for similar TBSA rates. $[5,11,14,15]$ Our mortality rate is lower than low-middle-income countries and is similar to that reported in developed countries. The comprehensive burn treatment approaches applied with an experienced team in our burn center might be the reason of low mortality rate.

\section{Conclusion}

Infants and males consist of the majority of our pediatric burn patients. The percentage of TBSA and length of hospital stay increased as the age of the patients increased. Childhood burn injuries are mainly scald burns that occur indoors, while their parents were nearby. Therefore, education programs focusing on primary prevention addressing family members are required to avoid scald burns. We think that preventive measures, guided by epidemiological data, will contribute to reduce the incidence and severity of burns in children and worth consideration.

Ethics Committee Approval: This study was approved by the Adana City Traning and Research Hospital Clinical Research Ethics Committee (Approval number: 461/2019, date: 22.05.2019).

Peer-review: Internally peer-reviewed.

Authorship Contributions: Concept: Ö.Ö., A.B.; Design: Ö.Ö., A.B.; Supervision: Ö.Ö., A.B.; Data: Ö.Ö., A.B.; Analysis: Ö.Ö., A.B.; Literature search: Ö.Ö., A.B.; Writing: Ö.Ö., A.B.; Critical revision: Ö.Ö., A.B.

Conflict of Interest: None declared.

Financial Disclosure: The authors declared that this study has received no financial support.

\section{REFERENCES}

1. Mock C, Peck M, Peden M, Krug E, editors. A WHO plan for burn prevention and care. Geneva, World Health Organization, 2008. Available from: https://apps.who.int/iris/bitstream/handle/10665/97852/9789241596299_eng.pdf? sequence $=1$ \&isAllowed $=y$.

2. Forjuoh SN. Burns in low-and middle-income countries: A review of available literature on descriptive epidemiology, risk factors, treatment, and prevention. Burns 2006;32:529-37. [CrossRef]

3. Ghorbel I, Bouaziz F, Loukil K, Moalla S, Gassara M, Ennouri K. Epidemiological profile of burns in children in central and southern Tunisia: A 67-case series. Arch Pediatr 2019;26:158-60. [CrossRef]

4. Smolle C, Cambiaso-Daniel J, Forbes AA, Wurzer P, Hundeshagen G, Branski LK, et al. Recent trends in burn epidemiology worldwide: A systematic review. Burns 2017;43:249-57. [CrossRef]

5. Saeman MR, Hodgman EI, Burris A, Wolf SE, Arnoldo BD, Kowalske $\mathrm{KJ}$, et al. Epidemiology and outcomes of pediatric burns over 35 years at Parkland Hospital. Burns 2016;42:202-8. [CrossRef]

6. Tarım A, Nursal TZ, Ylldırım S, Noyan T, Moray G, Haberal M. Epidemiology of pediatric burn injuries in Southern Turkey. J Burn Care Rehabil 2005;26:327-30. [CrossRef]

7. Oztorun CI, Demir S, Azili MN, Senayli A, Livanelioglu Z, Senel E. The outcomes of becoming a pediatric burn center in Turkey. Ulus Travma Acil Cerrahi Derg 2016;22:34-9. [CrossRef]

8. Dhopte A, Tiwari VK, Patel P, Bamal R. Epidemiology of pediatric burns and future prevention strategies-a study of 475 patients from a high-volume burn center in North India. Burns Trauma 2017;5:1. [CrossRef]

9. Oseni OG, Olamoyegun KD, Olaitan PB. Paediatric burn epidemiology as a basis for developing a burn prevention program. Ann Burns Fire Disasters 2017;30:247-9.

10. Wang S, Li D, Shen C, Chai J, Zhu H, Lin Y, et al. Epidemiology of burns in pediatric patients of Beijing city. BMC Pediatrics 2016;16:166. [CrossRef]

11. Trop M, Herzog SA, Pfurtscheller K, Hoebenreich AM, Schintler MV, Stockenhuber A, et al. The past 25 years of pediatric burn treatment in Graz and important lessons been learned. An overview. Burns 2015;41:714-20. [CrossRef]

12. Albayrak Y, Temiz A, Albayrak A, Peksoz R, Albayrak F, Tanrikulu Y. A retrospective analysis of 2713 hospitalized burn patients in a burns center in Turkey. Ulus Travma Acil Cerrahi Derg 2018;24:25-30. [CrossRef]

13. Coban YK, Erkilic A, Analay H. Our 18-month experience at a new burn center in Gaziantep, Turkey. Ulus Travma Acil Cerrahi Derg 2010;16:353-6.

14. Lee CJ, Mahendraraj K, Houng A, Marano M, Petrona S, Lee R, et al. Pediatric burns: A single institution retrospective review of incidence, etiology, and outcomes in 2273 burn patients (1995-2013). J Burn Care Res 2016;37:e579-85. [CrossRef]

15. Li H, Yao Z, Tan J, Zhou J, Li Y, Wu J, et al. Epidemiology and outcome analysis of 6325 burn patients: A five-year retrospective study in a major burn center in Southwest China. Sci Rep 2017;7:46066. [CrossRef]

16. Zheng Y, Lin G, Zhan R, Qian W, Yan T, Sun L, et al. Epidemiological analysis of 9,779 burn patients in China: An eight year retrospective study at a majör burn center in Southwest China. Exp Ther Med 2019;17:2847-54. [CrossRef]

17. Othman N, Kendrick D. Epidemiology of burn injuries in the East Mediterranean Region: A systematic review. BMC Public Health 2010;10:83.

18. Tegtmeyer LC, Herrnstadt GR, Maier SL, Thamm OC, Klinke M, Reinshagen $\mathrm{K}$, et al. Retrospective analysis on thermal injuries in children-demographic, etiological and clinical data of German and Austrian pediatric hospitals 2006-2015-approaching the new German burn registry. Burns 2018;44:150-7. [CrossRef] 
ORİJiNAL ÇALIŞMA - ÖZ

\section{2 pediatrik yanık hastasının epidemiyolojisi ve sonuçları: Tek merkez deneyimi}

\section{Dr. Özer Özlü, Dr. Abdulkadir Basaran}

Adana Şehir Eğitim ve Araştırma Hastanesi, Genel Cerrahi Anabilim Dalı, Adana

AMAÇ: Yanıklar özellikle gelişmekte olan ülkelerde çocuklarda sık görülen önemli bir mortalite ve morbidite sebebidir. Epidemiyolojik veriler, önleyici tedbirler için yol gösterebilir ve çocuklarda yanık olgularının azaltılmasına katkıda bulunabilir. Bu çalışmanın amacı yanık merkezinde yatarak tedavi edilen çocuk hastalarda yanıkların epidemiyolojik özelliklerini incelemek ve önleyici tedbirler önermektir.

GEREÇ VE YÖNTEM: Çalışmamızda I Ocak 20।5-30 Haziran 2019 tarihleri arasında 3. basamak yanık merkezine yatırılarak tedavi edilen I442 çocuk hastanın demografik ve epidemiyolojik verileri, yanık mekanizması, yanık etiyolojisi, yanık total vücut alanı yüzdesi (TBSA), tedavi sonuçları geriye dönük olarak değerlendirildi.

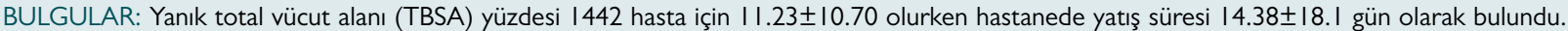
Hastaların \%89. I8'inde ( $n=1286)$ yanma olayı ev içerisinde gerçekleşmişti. Yanık etiyolojisinde tüm yaş gruplarında sıcak su ve çay ile yanma en sık görülürken, süt çocuğu döneminden sonra alev yanıkları artmakta, okul çağında elektrik yanıkları daha fazla görülmektedir. Toplam I0 hasta (\%0.69) hayatını kaybetti. Bunlardan yedisi başka hastanelerden gelen gecikmiş hastalardı.

TARTıŞMA: Yanık merkezimizdeki çocuk hastaların çoğunluğu süt çocuğu ve erkek hastalar idi. Yaş arttıkça TBSA oranları ve hastanede yatış süresi de artmakta idi. Çocuk yanıkları genellikle okul öncesi çocuklarda ev içerisinde ve yanlarında bir ebeveyn varken olmaktadır. Bu nedenle bu çocukların gözetimini yapan aile bireylerine yönelik eğitim programı ve farkındalık yaratacak çalışmalara ihtiyaç vardır.

Anahtar sözcükler: Epidemiyoloji; korunma; pediatrik hastalar; yanık.

Ulus Travma Acil Cerrahi Derg 2022;28(I):57-6I doi: 10.14744/tjtes.2020.69447 